\title{
The global, regional, and national burden of kidney cancer and attributable risk factor analysis from 1990 to 2017
}

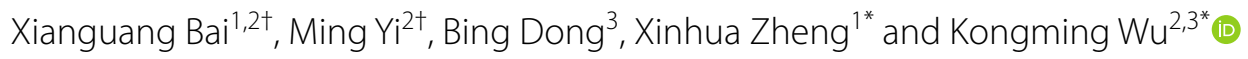

\begin{abstract}
Background: Kidney cancer's incidence and mortality vary in different regions and countries. To compare and interpret kidney cancer's burden and change trends in the globe and in different countries, we conducted this study to report the global kidney cancer burden and attributable risk factors.

Methods: Data about kidney cancer's incidence, death, disability-adjusted life-year (DALY) were extracted from the Global Burden of Diseases 2017. Besides, social-demographic index (SDI) values were adopted to investigate the correlation between kidney cancer's burden and social development degrees.

Results: In the globe, the incidence case of kidney cancer increased sharply from $207.31^{*} 10^{3}$ in 1990 to $393.04^{*} 10^{3}$ in 2017. High SDI countries had the highest kidney cancer's burden with a decreased trend in incidence rate. On the contrary, the incidence rate was rapidly increased in low-middle SDI countries, although their burden of kidney cancer kept relatively low. At the same time, the deaths of kidney cancer increased from $68.14^{*} 10^{3}$ to $138.53^{*} 10^{3}$, and the kidney cancer-related DALYs increased from $1915.49^{*} 10^{3}$ in 1990 to $3284.32^{*} 10^{3}$ in 2017. Then, we searched the GBD database for kidney cancer-related risk factor. The high body-mass index and smoking were the main factors contributing to kidney cancer-related mortality.

Conclusions: Generally, from 1990 to 2017, the incidence rate in developed countries had gone down from the historic peak values while the incidence rate was still on the rise in developing counties. Given the aging trend in the globe, it is necessary to appeal to the public to decrease the exposure of kidney cancer-associated risk factors.
\end{abstract}

Keywords: Kidney cancer, Social-demographic index, Global burden of diseases, Cancer epidemiology, Attributable risk factor

\section{Background}

Kidney cancer is a common genitourinary malignancy with poor prognosis. In 2019, kidney cancer was the sixth most commonly diagnosed cancer in males and the eighth in females in the United States [1]. In

\footnotetext{
*Correspondence: zhengxinhua70@163.com; kmwu@tjh.tjmu.edu.cn ${ }^{+}$Xianguang Bai and Ming Yi contributed equally to this work

1 Medical School of Pingdingshan University, Pingdingshan, Henan, China

2 Department of Oncology, Tongji Hospital of Tongji Medical College, Huazhong University of Science and Technology, Wuhan, Hubei, China

Full list of author information is available at the end of the article
}

general, the incidence of kidney cancer predominates in males, and the ratio of male to female is approximately 1.5:1 [2]. Besides, the incidence rate of kidney cancer varies in different countries, which is commonly higher in developed countries than in developing countries [3]. Although the incidence keeps increasing, the relative survival rate of kidney cancer has been dramatically improved during the past three decades [4]. In the United States, the 5-year survival rate of kidney cancer increased from nearly $50 \%$ in the 1970 s to $57 \%$ in the 1980 s, then reached $73 \%$ in the 2000s [5]. The increasing understanding of kidney cancer's molecular biology

c) The Author(s) 2020. This article is licensed under a Creative Commons Attribution 4.0 International License, which permits use, sharing, adaptation, distribution and reproduction in any medium or format, as long as you give appropriate credit to the original author(s) and the source, provide a link to the Creative Commons licence, and indicate if changes were made. The images or other third party material in this article are included in the article's Creative Commons licence, unless indicated otherwise in a credit line to the material. If material is not included in the article's Creative Commons licence and your intended use is not permitted by statutory regulation or exceeds the permitted use, you will need to obtain permission directly from the copyright holder. To view a copy of this licence, visit http://creativeco mmons.org/licenses/by/4.0/. The Creative Commons Public Domain Dedication waiver (http://creativecommons.org/publicdomain/ zero/1.0/) applies to the data made available in this article, unless otherwise stated in a credit line to the data. 
and cytogenetic propels the development of systemic treatment strategy. In the past decade, several targeted agents were developed and entered into clinical studies. Antiangiogenic agents such as Bevacizumab, Sorafenib, and Sunitinib have been approved for kidney cancer treatment [6, 7]. Besides, agents targeting the mTOR pathway, such as Temsirolimus and Everolimus, have also been approved for metastatic kidney cancer treatment [8].

Moreover, because kidney cancer cells tend to harbor frequent frameshift mutations, kidney cancer always has strong immunogenicity and is suitable for immunotherapy $[9,10]$. Antibodies targeting programmed cell death 1 (PD-1) or PD-L1 such as Nivolumab, showed a potent and durable anti-cancer effect in kidney cancer patients [11]. Apart from a single agent, combination therapy is another promising treatment strategy. Immune checkpoint inhibitor combining antiangiogenic agents exhibited a synergistic effect for kidney cancer [12, 13].

Kidney cancer is a heterogeneous panel of tumors with various genetic alterations and molecular changes [14, 15]. Renal clear cell, chromophobe, and papillary carcinomas are the most commonly diagnosed solid renal cancers, which account for over $85 \%$ of all kidney malignancies [14]. Up to now, the mechanisms by which kidney cancer initiates and develops are still unclear. In most kidney cancer tissues, the structural changes in the short arm of chromosome 3 could be detected [16]. Over $80 \%$ of renal clear cell cancer patients harbor the genetic or epigenetic alteration of $V H L$ (a cancer suppressor gene), which participates in oxygen sensing and proteasome degradation [17]. Besides, a group of other gene mutations, including PBRM1, BAP1, SETD2, and TCEB1, also play an essential role in kidney cancer initiation and development [18-21].

Moreover, some lifestyle risk factors, such as obesity and tobacco exposure, have been documented to increase the risk of kidney cancer [22, 23]. Smoking increased the risk of renal cell carcinoma by $50 \%$ in males and by $20 \%$ in females [24]. A rise of $5 \mathrm{~kg} / \mathrm{m}^{2}$ in body mass index elevated the risk of renal cell carcinoma by $24 \%$ in males and $34 \%$ in females [25]. Besides, hypertension and low consumption of fruit or vegetable were related to the increased risk of kidney cancer [26, 27].

Although kidney cancer is a severe health threat in the globe, a comprehensive assessment of incidence, death, and disability-adjusted life-year (DALY) is not available until now. Based on the data from the GBD 2017 database, we estimated the global, regional, and national burden of kidney cancer from 1990 to 2017, which might be meaningful for policy-makers to allocate healthy resources rationally.

\section{Methods}

\section{Data acquisition}

Global Burden of Diseases 2017 (GBD 2017) database contains the burdens of 354 diseases in the globe, different geographic areas, and 195 countries and territories [28-32]. Data about kidney cancer's incidence, death, DALY, as well as their corresponding age-standardized rates (ASRs), were downloaded by the Global Health Data Exchange (GHDx) (website: http://ghdx. healthdata.org/gbd-results-tool). In the meanwhile, the information about the distributions of sex and age was also acquired. SDI value is the average of total fertility, per capita income, and the years of education, which is developed to reflect social development degree. As previous studies documented, social development degree might affect the incidence and mortality of kidney cancer. Thus we obtained the social-demographic index (SDI) values to investigate the correlation between kidney cancer's burden and social development degrees in different countries.

\section{Statistical analysis}

The numbers of incidence, death, and DALY were the main parameters evaluating the burden of kidney cancer. To avoid the interferences of population change and age distribution difference, age-standardized incidence rate, death rate (abbreviated as ASIR and ASDR, respectively), and DALY rate were also used. To track the dynamic changes of disease burden, we used a statistical model termed estimated annual percentage changes (EAPCs), which was calculated based on ASRs following the formula below: $y=\alpha+\beta x$. In this formula, $\mathrm{x}$ refers to year and y presents $\log 10$ (ASRs). Then, EAPC values could be obtained by EAPC $=100^{*}\left(10^{\wedge} \beta-1\right)$. If the EAPC value and its $95 \% \mathrm{CI}$ are above zero, the corresponding change trend will be upwards, and vice versa. Besides, by Pearson's correlation test model, we analyzed the strengths of correlation between SDI values and ASRs.

\section{Data visualization}

Data visualization was performed by $\mathrm{R}$ software (version: 3.6.0). The burden of kidney cancer in different countries or territories was presented via world maps. In this study, packages maps, ggplot2, and dplyr were used.

\section{Results}

Kidney cancer's incidence, incidence rate, and change trends

From a global perspective, the incidence case of kidney cancer increased sharply from $207.31^{*} 10^{3}$ in 1990 to $393.04 * 10^{3}$ in 2017 (Table 1). Kidney cancer mainly occurred in males (the ratio of male patients to female patients: $1.24: 1$ in 1990 and 1.58:1 in 2017). Offsetting 
Table 1 The incidence of kidney cancer in 1990/2017 and temporal trends

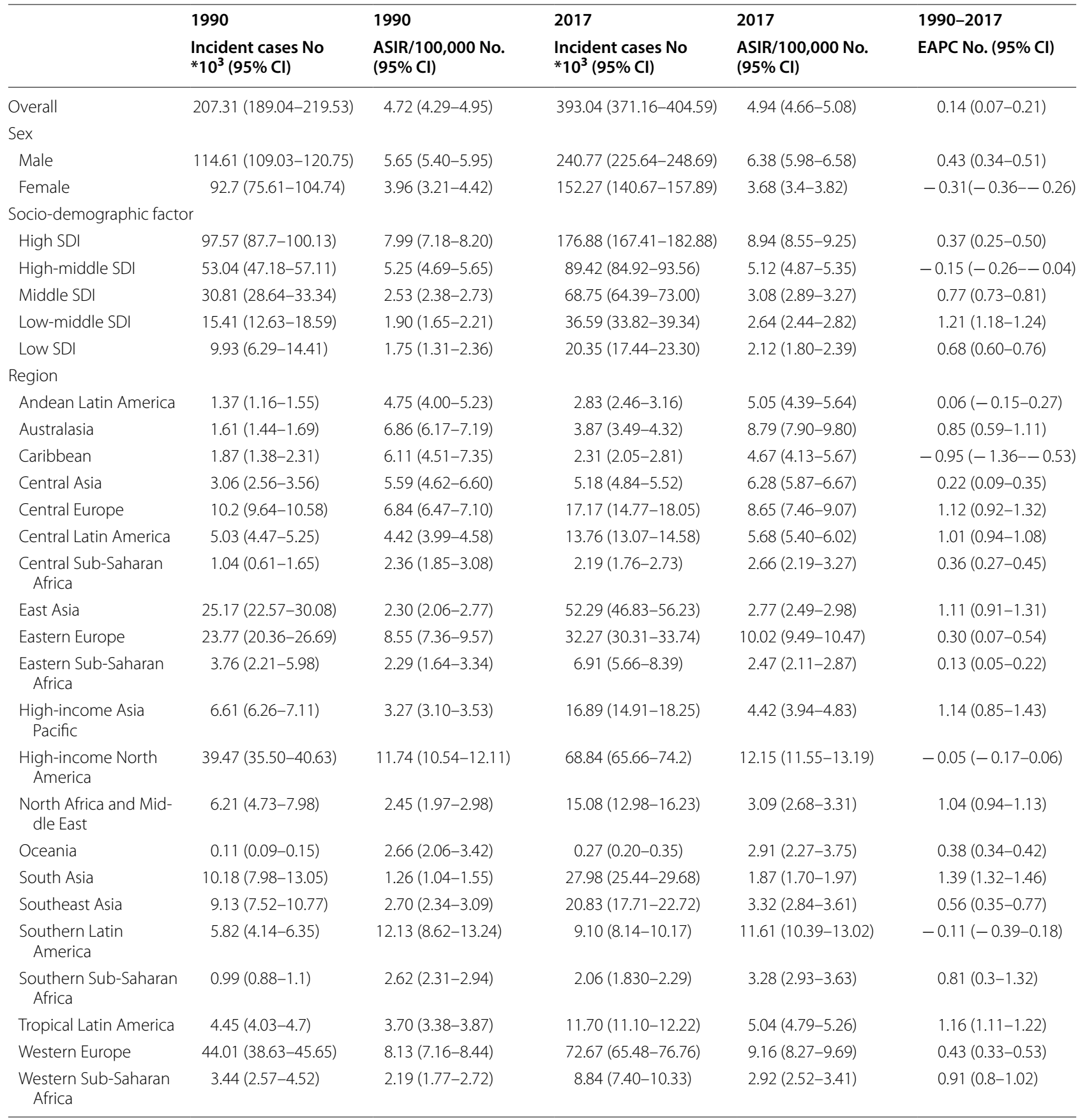

the differences in population size and age distribution between males and females, males indeed had a higher risk of developing kidney cancer than females (the ratio of male's ASIR to female's ASIR: 1.43 in 1990 and 1.73 in 2017). At the same time, the growth speed of incidence rate in males was faster than in females (EAPC of male: 0.43, 95\% CI 0.34-0.51; EAPC of female: $-0.31,95 \%$ CI -0.36 to -0.26$)$. In terms of social development degree, the incidence and ASIR were significantly higher in high SDI countries (Figs. 1a and 2a). Notably, the incidence rate elevated rapidly in low-middle SDI countries (EAPC: 1.21, 95\% CI 1.18-1.24). Then, for different geographic areas, Western Europe had the most incidence cases (incidence: $44.01^{*} 10^{3}$ in 1990 and $72.67 * 10^{3}$ in 2017), and the high-income North America zone had the highest ASIR (ASIR: 11.74 in 1990 and 12.15 in 2017). South Asia 
(See figure on next page.)

Fig. 1 The change trends of kidney cancer's incidence cases, deaths, and DALYs from 1990 to 2017. a The change trends of incidences; $\mathbf{b}$ the change trends of deaths; $\mathbf{c}$ the change trends of DALYs. Note: DALY, disability-adjusted life year

had the fastest increase in ASIR during the past 28 years (EAPC: 1.39 , 95\% CI 1.32-1.46). As for a specific country, the United States and China had the most incidence

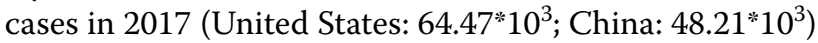
(Fig. 3a). Uruguay and Slovakia had the highest ASIR in 2017 (Uruguay: 15.79; Slovakia: 14.14) (Fig. 4a).

\section{Kidney cancer's death, death rate, and change trends} In the globe, the deaths of kidney cancer increased from $68.14^{*} 10^{3}$ in 1990 to $138.53^{*} 10^{3}$ in 2017 (Table 2) (Fig. 1b). Subgroup analysis by sex showed that males contributed more to the mushrooming kidney cancerrelated deaths than females (total death number of males in 2017: 89.62*1 $10^{3}$; total death number of females in 2017: 48.91*103\% : EAPC of males: 0.37, 95\% CI 0.31-0.44; EAPC of females: $-0.32,95 \%$ CI -0.37 to -0.28 ). Subgroup analysis by SDI values showed that kidney cancer-related death mainly occurred in high SDI countries (death cases: $36.13^{*} 10^{3}$ in 1990 and $66.86^{*} 10^{3}$ in 2017; ASDR: 2.81 in 1990 and 2.97 in 2017). At the same time, the ASDR was rapidly elevated in low-middle SDI countries (ASDR: 0.61 in 1990 and 0.84 in 2017; EAPC: 1.20, 95\% CI 1.16-1.23) (Fig. 2b). Subgroup analysis by geographic area demonstrated that Western Europe had the most kidney cancerrelated deaths $\left(18.58^{*} 10^{3}\right.$ in 1990 and $30.33^{*} 10^{3}$ in 2017), and Southern Latin America had the highest ASDR (4.61 in 1990 and 4.28 in 2017). Besides, the growth speed of ASDR in East Asia was fastest (EAPC: 2.01, 95\% CI 1.782.23). In the level of country or territory, China and the United States had the most kidney cancer-related deaths in $2017\left(17.17^{*} 10^{3}\right.$ and $17.06^{*} 10^{3}$, respectively) (Fig. 3b). Besides, the Czech Republic and Uruguay had the highest ASDR in 2017 (Czech Republic: 5.57; Uruguay: 5.54) (Fig. 4b).

\section{Kidney cancer's DALY, DALY rate, and change trends}

In the global level, the kidney cancer-related DALYs were increased from $1915.49^{*} 10^{3}$ in 1990 to $3284.32^{*} 10^{3}$ in 2017 (Table 3) (Fig. 1c). Most DALYs were contributed by males (DALYs of males in 1990: $1157.59^{*} 10^{3}$; DALY in 2017: $\left.2166.29^{*} 10^{3}\right)$. Subgroup analysis by SDI values showed that high SDI countries had the most DALYs $\left(828.98^{*} 10^{3}\right.$ in 1990 and $1289.66^{*} 10^{3}$ in 2017). Low-middle SDI countries had the fastest rise in age-standardized DALY rate at the same time $(\mathrm{EAPC}=0.93,95 \% \mathrm{CI}$ 0.89-0.96) (Fig. 2c). For different geographic areas, Western Europe had the highest DALY burden $\left(405.97^{*} 10^{3}\right.$ in 1990 and $553.19^{*} 10^{3}$ in 2017). At the same time, East
Asia had the most rapid increase in age-standardized DALY rate (age-standardized DALY rate: 20.84 in 1990 and 25.15 in 2017, $\mathrm{EAPC}=1.13,95 \%$ CI $0.92-1.33$ ). In the level of country or territory, China and the United States had the highest DALY burden in $2017\left(438.14^{*} 10^{3}\right.$ and $368.08 * 10^{3}$, respectively) (Fig. 3c). Besides, Uruguay and the Czech Republic had the highest age-standardized DALY rate in 2017 (138.90 and 119.98, respectively) (Fig. 4c).

\section{The correlation analysis between SDI value and kidney cancer's burden}

To explore the potential correlation between social development degree and kidney cancer's burden, we conducted a correlation analysis between SDI values and ASRs in 21 different geographic areas from 1990 to 2017. The results indicated that ASRs were significantly positively correlated to SDI values (coefficient of ASIR-SDI: 0.75, of ASDR-SDI: 0.77, of age-standardized DALY rateSDI: 0.71; all $\mathrm{P}$ values $<0.0001$ ) (Fig. $5 \mathrm{a}-\mathrm{c}$ ).

\section{Age distribution}

Age distribution is a vital parameter of cancer epidemiology. In the globe, nearly $77 \%$ of kidney cancer patients aged 50 years or older in 2017 (Fig. 6a). This ratio reached $88 \%$ in the high SDI counties. Relatively, the ratio of older patients was lower in low SDI countries (just 45\% of patients aged 50 years or older). Notably, for the age group under 5 years, kidney cancer's incidence in males and females was roughly similar. However, for the age group above 70 years or older, male patients far outnumbered female patients in 2017 (male patients: 72.61*10 and female patients: $\left.48.43^{*} 10^{3}\right)$. Generally, in countries with different SDI values, the ASIR was highest in the patients aged 70 years or older (Fig. 6b).

\section{Attributable risk factors}

We searched the GBD database for risk factors contributing to kidney cancer-related mortality. Eventually, we found that high body-mass index, smoking, occupational exposure to trichloroethylene were mainly attributable risk factors of kidney cancer-related mortality. Among them, high body-mass index and smoking were leading risk factors of kidney cancer-related death and DALY (Fig. 7a, b). The contribution ratio of occupational exposure to trichloroethylene was relatively weak. 
a

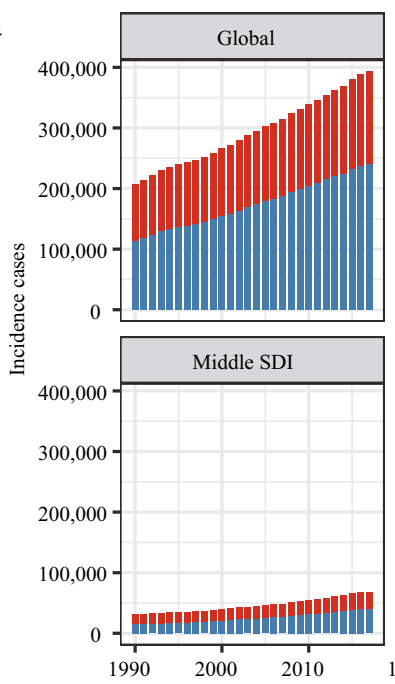

b

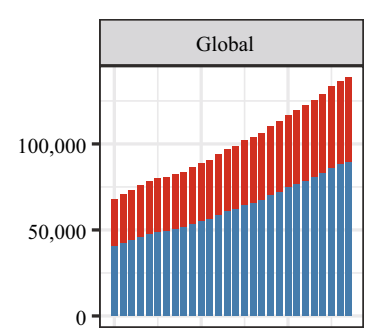

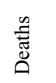

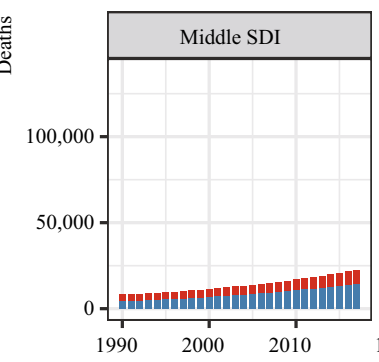

c

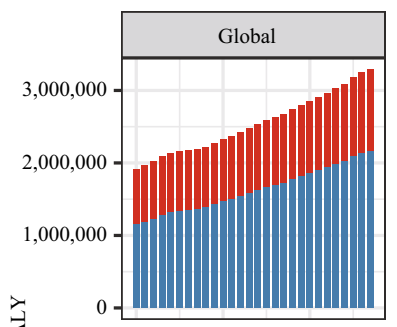

它

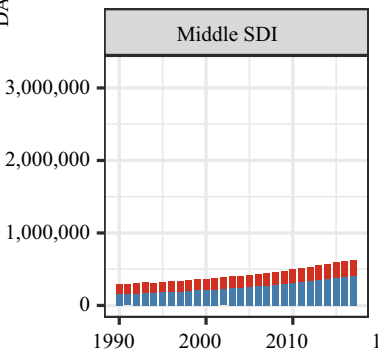

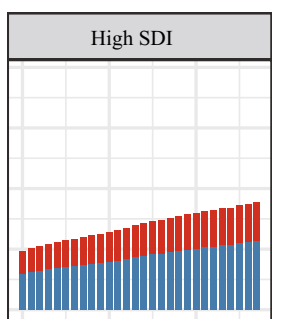
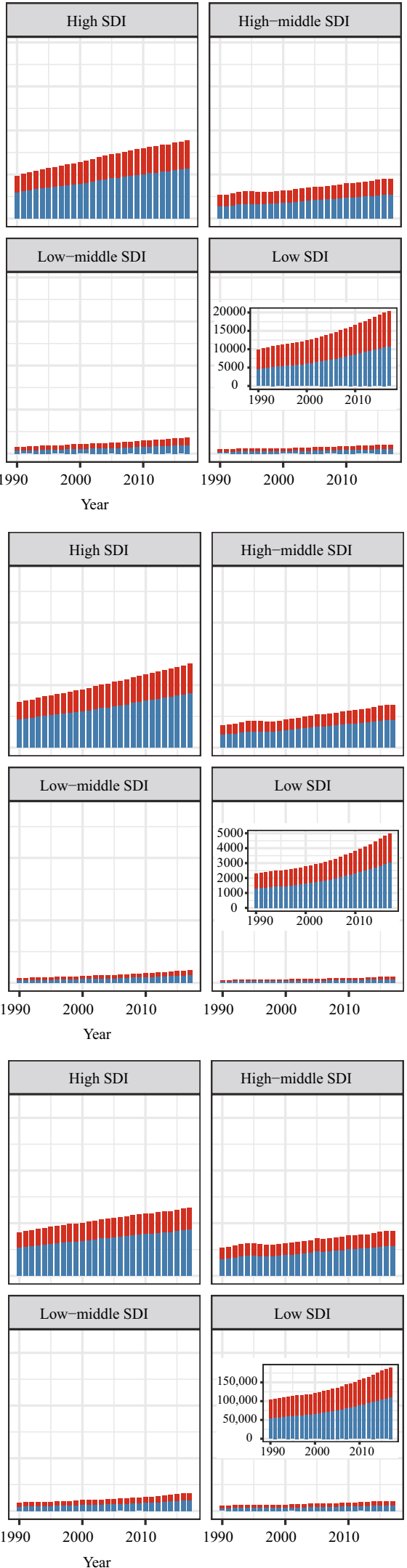
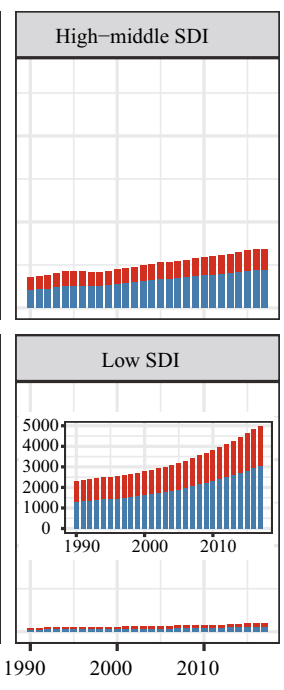

Sex

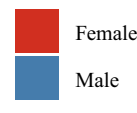

Sex Female Male

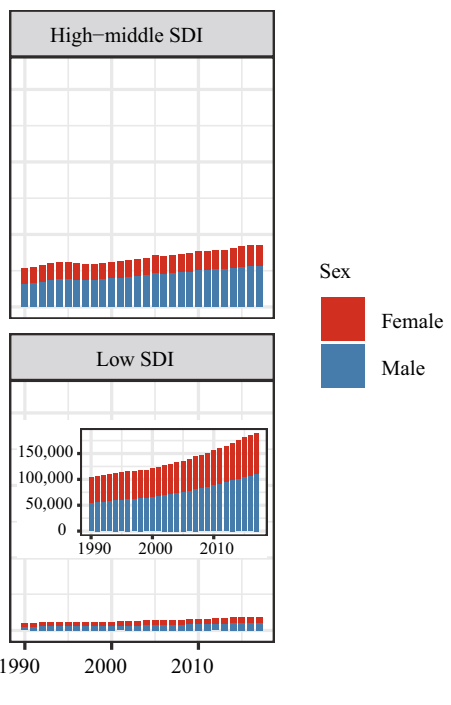




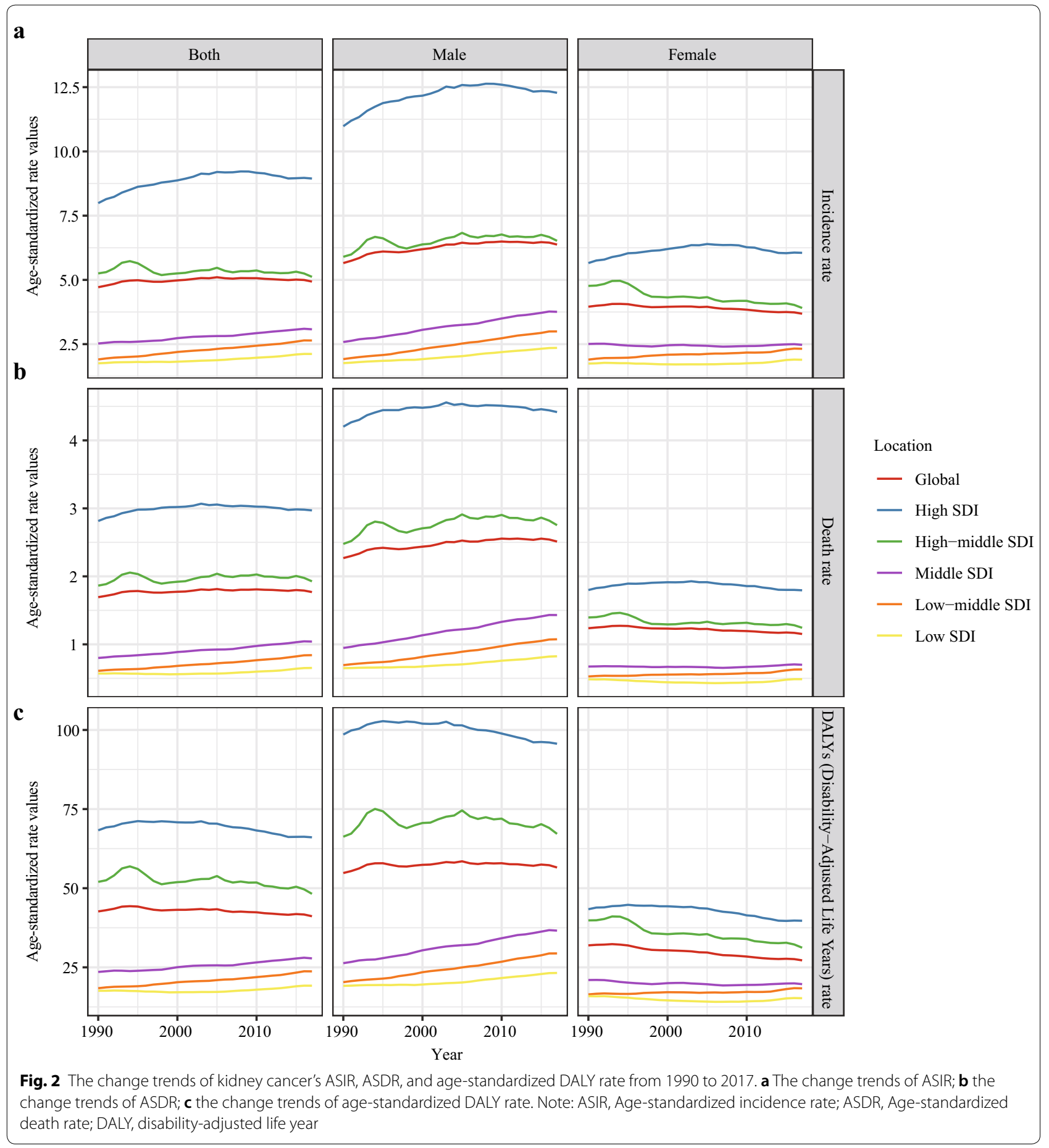

\section{Discussion}

In this study, we comprehensively analyzed the burden of kidney cancer and attributable risk factors. A previous GLOBOCAN-based cancer epidemiologic study showed that kidney cancer's incidence rate kept increasing in most countries [33]. In some high-income developed areas such as the United States, Western and Northern Europe, and Australia, the kidney cancer-related mortality rate kept a high level in the globe but began to decline from its peak value recently [33]. Contrarily, in Africa and most Asian countries, the incidence rate of kidney cancer was relatively low but increased rapidly in the past 


\section{$\mathbf{a}$}
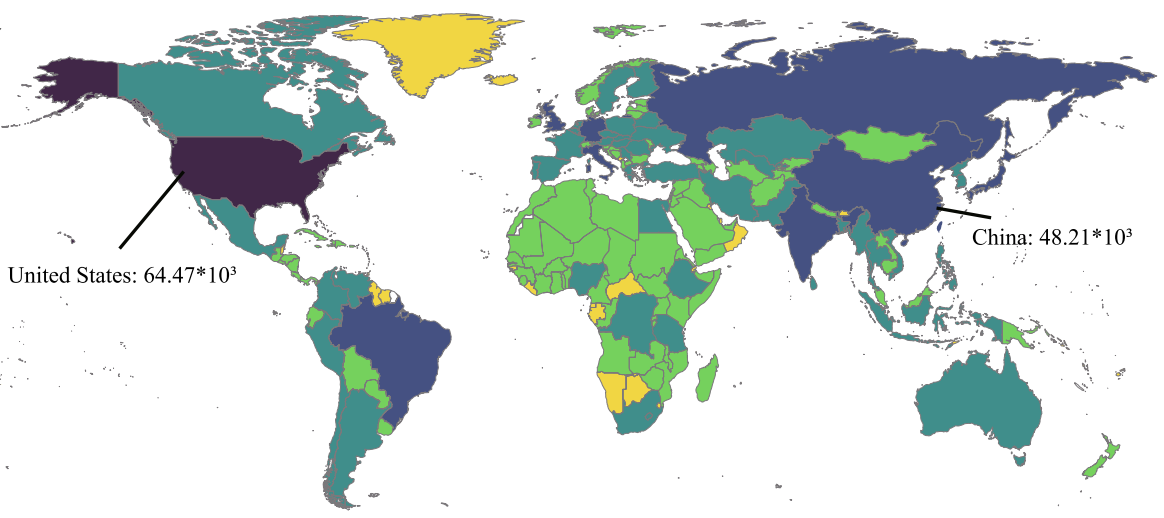

Incidence

$<100$

$100 \sim 1000$

$1000 \sim 10000$

$10000 \sim 50000$

$>50000$
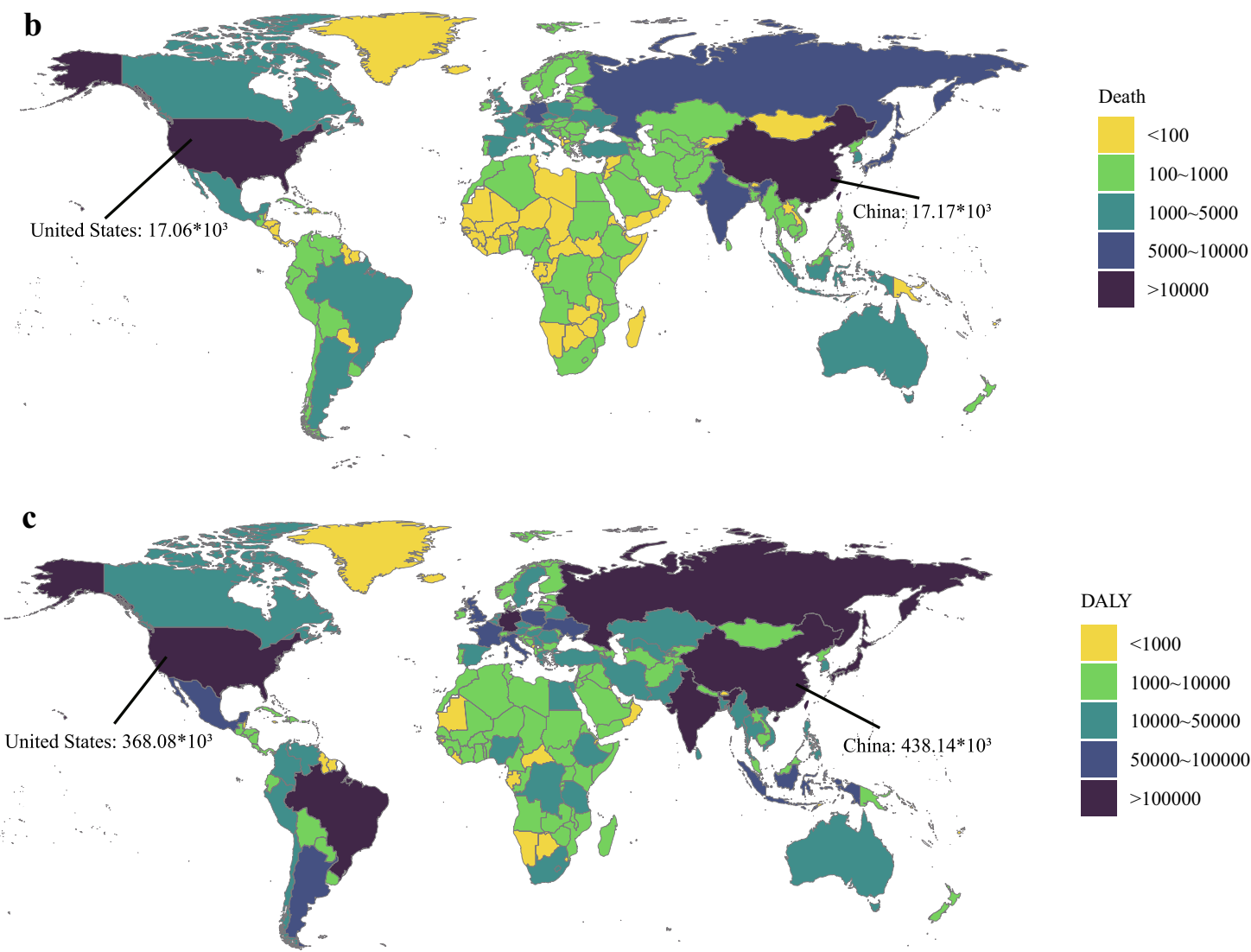

DALY

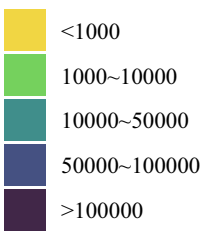

Fig. 3 The global disease burden of kidney cancer in 195 countries or territories. a The incidence cases of 195 countries in 2017; $\mathbf{b}$ the deaths of 195 countries in 2017; c the DALYs of 195 countries in 2017. Note: DALY, disability-adjusted life year

decades [33]. Similarly to the results of a GLOBOCAN database-based study, our study showed SDI value was significantly positively correlated to ASIR, ASDR, and age-standardized DALY rate. This increased ASIR in high SDI countries could be attributed to multiple factors, which included but were not limited to cancer registry system, aging, smoking, obesity, and hypertension [34].
Besides, more widely used abdominal cross-sectional imaging technology also contributes to a larger number of incidental diagnosis of kidney cancer in developed countries [35]. Notably, although both incidence rate and mortality rate were higher in developed countries, the mortality-to-incidence ratio was lower in these countries simultaneously [35]. This disparity might closely 


\section{a}
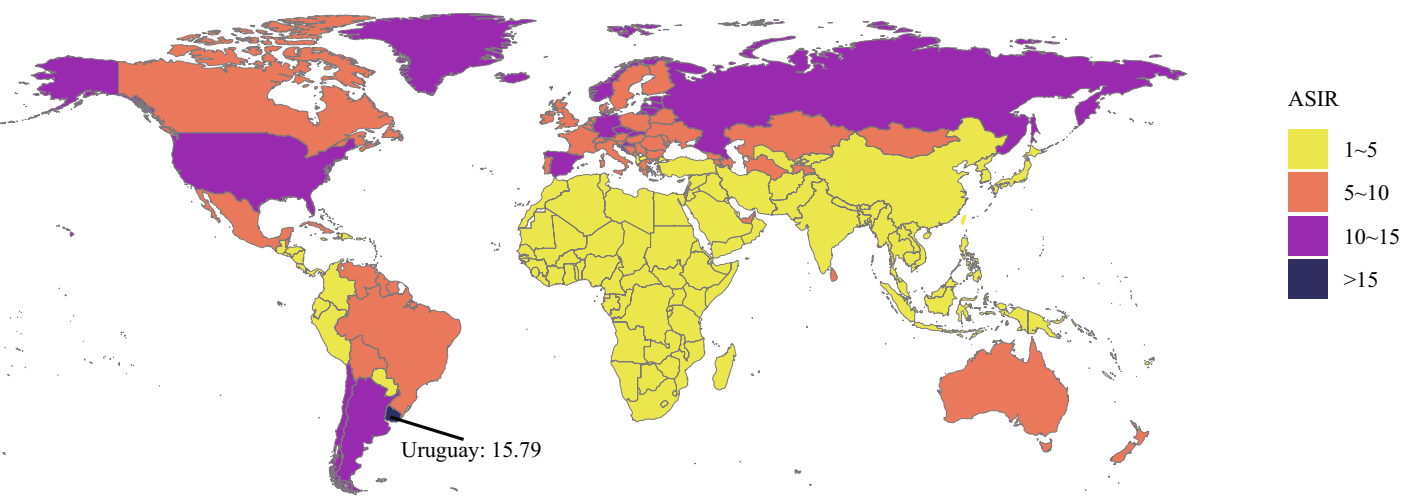

b

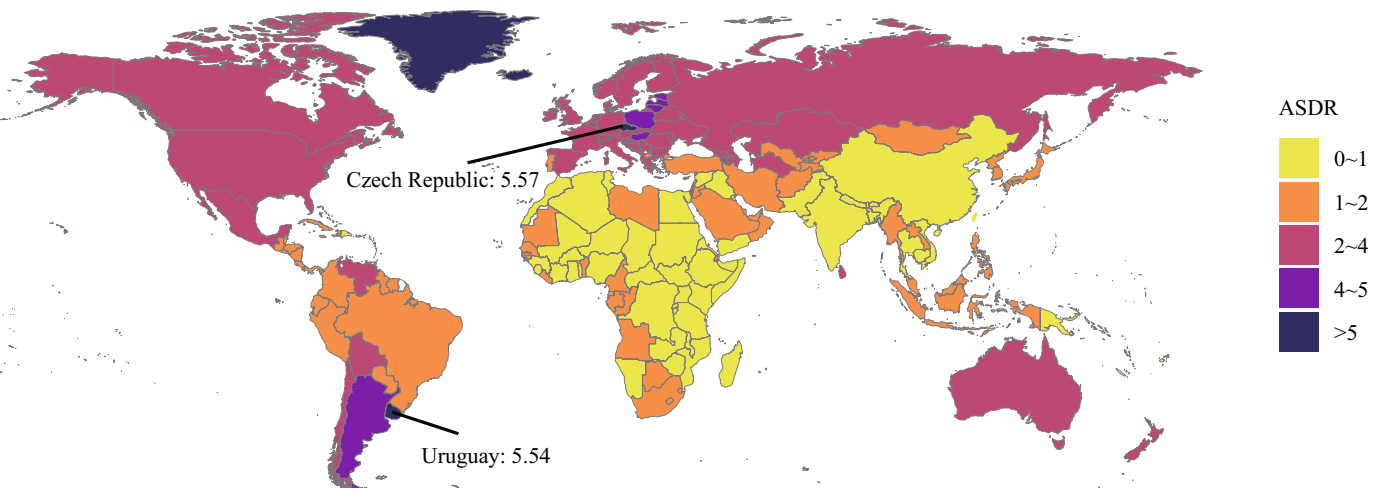

c

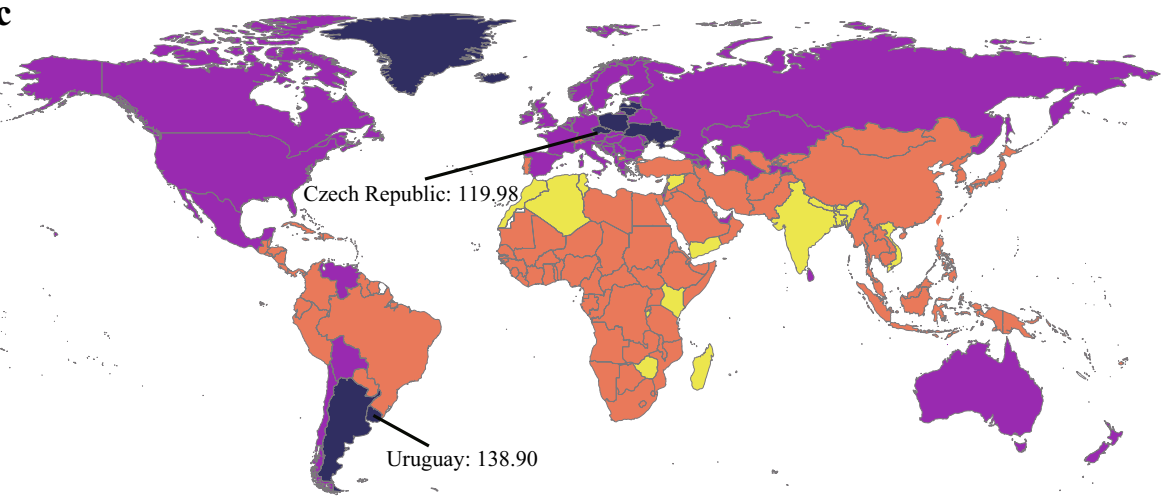

Age-standardized DALY rate

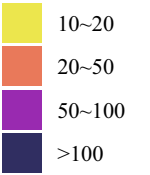

Fig. 4 The age-standardized rates of kidney cancer in 195 countries or territories. a The ASIR of 195 countries in 2017; b the ASDR of 195 countries in 2017; c the age-standardized DALY rate of 195 countries in 2017. Note: ASIR, Age-standardized incidence rate; ASDR, Age-standardized death rate; DALY, disability-adjusted life year

associate with the quality and availability of health care [35].

In the context of the aging in the globe, the increasing trend of kidney cancer burden is likely to continue in the future. Therefore, policy-makers need to take action to relieve this trend. Decreasing the influence of some attributable risk factors such as high body-mass index and smoking is feasible to alleviate the growing burden of kidney cancer. The correlation between obesity and kidney cancer has been a concern for a long time [36]. A previously retrospective study showed that each additional body-mass index value increased the relative risk ratio of kidney cancer by 7\% [37]. Later, another perspective study proved that a high body-mass index was an 
Table 2 The death of kidney cancer in 1990/2017 and temporal trends

\begin{tabular}{|c|c|c|c|c|c|}
\hline & 1990 & 1990 & 2017 & 2017 & 1990-2017 \\
\hline & $\begin{array}{l}\text { Death cases No * } 10^{3}(95 \% \\
\mathrm{CI})\end{array}$ & $\begin{array}{l}\text { ASDR/100,000 } \\
\text { No. }(95 \% \mathrm{Cl})\end{array}$ & $\begin{array}{l}\text { Death cases No * } 10^{3}(95 \% \\
\text { CI) }\end{array}$ & $\begin{array}{l}\text { ASDR/100,000 } \\
\text { No. }(95 \% \mathrm{Cl})\end{array}$ & EAPC No. $(95 \% \mathrm{CI})$ \\
\hline Overall & $68.14(62.73-70.8)$ & $1.69(1.56-1.75)$ & $138.53(128.66-142.52)$ & $1.77(1.64-1.82)$ & $0.13(0.07-0.19)$ \\
\hline \multicolumn{6}{|l|}{ Sex } \\
\hline Male & $40.97(39.1-42.75)$ & $2.27(2.17-2.36)$ & $89.62(84.64-92.52)$ & $2.51(2.38-2.59)$ & $0.37(0.31-0.44)$ \\
\hline Female & $27.17(21.98-29.44)$ & $1.24(1-1.33)$ & $48.91(42.92-50.65)$ & $1.15(1.01-1.19)$ & $-0.32(-0.37--0.28)$ \\
\hline \multicolumn{6}{|l|}{ Socio-demographic factor } \\
\hline High SDI & $36.13(32.66-36.86)$ & $2.81(2.54-2.87)$ & $66.86(60.67-69.15)$ & $2.97(2.73-3.07)$ & $0.13(0.04-0.21)$ \\
\hline High-middle SDI & $17.74(16.05-18.97)$ & $1.86(1.7-1.99)$ & $33.90(31.85-35.32)$ & $1.93(1.81-2.01)$ & $0.11(-0.01-0.22)$ \\
\hline Middle SDI & $8.00(7.53-8.66)$ & $0.80(0.75-0.87)$ & $22.32(20.93-23.78)$ & $1.04(0.98-1.11)$ & $0.99(0.96-1.02)$ \\
\hline Low-middle SDI & $3.84(3.36-4.46)$ & $0.61(0.53-0.69)$ & $10.08(9.36-10.77)$ & $0.84(0.78-0.90)$ & $1.20(1.16-1.23)$ \\
\hline Low SDI & $2.29(1.7-3.15)$ & $0.57(0.43-0.73)$ & $4.97(4.21-5.55)$ & $0.65(0.55-0.73)$ & $0.47(0.34-0.60)$ \\
\hline \multicolumn{6}{|l|}{ Region } \\
\hline Andean Latin America & $0.37(0.33-0.40)$ & $1.6(1.39-1.72)$ & $0.98(0.84-1.09)$ & $1.82(1.56-2.03)$ & $0.36(0.17-0.54)$ \\
\hline Australasia & $0.79(0.69-0.82)$ & $3.27(2.86-3.4)$ & $1.59(1.44-1.74)$ & $3.27(2.97-3.59)$ & $-0.19(-0.25--0.13)$ \\
\hline Caribbean & $0.54(0.41-0.61)$ & $1.94(1.48-2.16)$ & $0.76(0.70-0.90)$ & $1.51(1.39-1.77)$ & $-0.88(-1.29--0.48)$ \\
\hline Central Asia & $0.91(0.75-1.08)$ & $1.79(1.46-2.14)$ & $1.70(1.61-1.79)$ & $2.24(2.13-2.36)$ & $0.66(0.52-0.79)$ \\
\hline Central Europe & $4.20(4.02-4.31)$ & $2.78(2.66-2.86)$ & $8.10(7.04-8.5)$ & $3.81(3.32-3.99)$ & $1.37(1.14-1.6)$ \\
\hline Central Latin America & $1.50(1.36-1.54)$ & $1.59(1.46-1.64)$ & $4.54(4.31-4.80)$ & $1.95(1.85-2.06)$ & $0.78(0.71-0.85)$ \\
\hline Central Sub-Saharan Africa & $0.23(0.18-0.31)$ & $0.79(0.61-0.97)$ & $0.49(0.41-0.60)$ & $0.85(0.68-1.11)$ & $0.15(-0.04-0.33)$ \\
\hline East Asia & $6.05(5.43-7.66)$ & $0.65(0.58-0.84)$ & 18.63 (16.49-19.99) & $0.97(0.86-1.04)$ & $2.01(1.78-2.23)$ \\
\hline Eastern Europe & $8.81(7.75-9.79)$ & $3.07(2.71-3.4)$ & $12.95(12.18-13.37)$ & $3.78(3.58-3.9)$ & $0.56(0.3-0.82)$ \\
\hline Eastern Sub-Saharan Africa & $0.77(0.54-1.15)$ & $0.73(0.57-0.98)$ & $1.47(1.26-1.70)$ & $0.77(0.67-0.88)$ & $0.04(-0.06-0.14)$ \\
\hline High-income Asia Pacific & $3.08(3.00-3.29)$ & $1.53(1.49-1.64)$ & $8.97(7.76-9.52)$ & $1.91(1.69-2.03)$ & $0.78(0.57-0.99)$ \\
\hline $\begin{array}{l}\text { High-income North } \\
\text { America }\end{array}$ & $11.12(10.08-11.36)$ & $3.14(2.85-3.21)$ & 19.05 (18.30-20.09) & $3.11(2.98-3.29)$ & $-0.26(-0.36--0.16)$ \\
\hline $\begin{array}{l}\text { North Africa and Middle } \\
\text { East }\end{array}$ & $1.67(1.37-2.03)$ & $0.85(0.69-0.99)$ & $4.50(3.91-4.82)$ & $1.07(0.93-1.15)$ & $1.06(0.92-1.2)$ \\
\hline Oceania & $0.02(0.02-0.03)$ & $0.75(0.58-0.97)$ & $0.06(0.05-0.07)$ & $0.85(0.68-1.08)$ & $0.5(0.45-0.54)$ \\
\hline South Asia & $2.82(2.33-3.46)$ & $0.45(0.36-0.54)$ & $8.32(7.51-8.8)$ & $0.62(0.56-0.66)$ & $1.16(1.03-1.28)$ \\
\hline Southeast Asia & $2.10(1.86-2.36)$ & $0.77(0.69-0.86)$ & $5.97(5.10-6.47)$ & $1.04(0.89-1.12)$ & $0.79(0.53-1.05)$ \\
\hline Southern Latin America & $2.19(1.64-2.31)$ & $4.61(3.46-4.85)$ & $3.49(3.19-3.86)$ & $4.28(3.9-4.72)$ & $-0.28(-0.52--0.05)$ \\
\hline $\begin{array}{l}\text { Southern Sub-Saharan } \\
\text { Africa }\end{array}$ & $0.28(0.24-0.31)$ & $0.91(0.78-1.04)$ & $0.63(0.56-0.69)$ & $1.13(1.01-1.24)$ & $0.83(0.48-1.18)$ \\
\hline Tropical Latin America & $1.29(1.2-1.34)$ & $1.29(1.21-1.34)$ & $4.03(3.81-4.21)$ & $1.76(1.67-1.84)$ & $1.17(1.13-1.21)$ \\
\hline Western Europe & 18.58 (16.37-19.09) & $3.16(2.78-3.24)$ & $30.33(27.10-31.84)$ & $3.26(2.95-3.43)$ & $0.06(0.02-0.1)$ \\
\hline Western Sub-Saharan Africa & $0.81(0.65-1.00)$ & $0.73(0.61-0.88)$ & $1.96(1.70-2.27)$ & $0.91(0.79-1.06)$ & $0.72(0.63-0.81)$ \\
\hline
\end{tabular}

independent prognostic factor for kidney cancer (Hazard Ratio $=1.71$ ) [38]. The mechanisms by which obesity affects the incidence and survival of kidney cancer might include insulin/insulin-like growth factor signals, chronic inflammation, sex steroids, as well as the treatment disparities between obese patients and normal-weight patients [39].

Tobacco smoking is another vital risk factor contributing to kidney cancer-related mortality. A previous metaanalysis showed that smoking markedly increased the risk of kidney cancer's incidence and disease-specific mortality [40]. The biologic mechanisms by which smoking induces and promotes kidney cancer are still unclear [41]. However, smoking could certainly cause renal damage by multiple manners, including oxidative stress, tubulotoxic effect, endothelial cell dysfunction, and hemodynamic change [42]. These cytotoxic activities increase cell turnover and lead to DNA damage, which might involve in cancer initiation and progression [42]. Additionally, smoking is closely related to some genetic or epigenetic alterations such as gene mutations and methylations [42]. Therefore, it is essential to emphasize 
Table 3 The DALY of kidney cancer in 1990/2017 and temporal trends

\begin{tabular}{|c|c|c|c|c|c|}
\hline & 1990 & 1990 & 2017 & 2017 & 1990-2017 \\
\hline & $\begin{array}{l}\text { DALY No } * 10^{3}(95 \% \\
\text { Cl) }\end{array}$ & $\begin{array}{l}\text { Average standardized } \\
\text { DALY rate/100,000 } \\
\text { No. }(95 \% \mathrm{Cl})\end{array}$ & $\begin{array}{l}\text { DALY No } * 10^{3}(95 \% \\
\text { Cl) }\end{array}$ & $\begin{array}{l}\text { Average standardized } \\
\text { DALY rate/100,000 } \\
\text { No. }(95 \% \mathrm{Cl})\end{array}$ & EAPC No. $(95 \% \mathrm{CI})$ \\
\hline Overall & $\begin{array}{l}1915.49(1735.86- \\
2037.43)\end{array}$ & 42.66 (38.85-44.93) & $\begin{array}{l}3284.32(3085.56- \\
3393.16)\end{array}$ & 41.14 (38.66-42.49) & $-0.20(-0.25--0.14)$ \\
\hline \multicolumn{6}{|l|}{ Sex } \\
\hline Male & $\begin{array}{l}1157.59(1093.79- \\
1226.54)\end{array}$ & $54.80(52.05-57.55)$ & $\begin{array}{l}2166.29(2026.86- \\
2241.74)\end{array}$ & $56.55(52.96-58.47)$ & $0.07(0.003-0.13)$ \\
\hline Female & 757.89 (611.81-865.34) & $31.94(25.65-35.98)$ & $\begin{array}{l}1118.03(1030.18- \\
1163.02)\end{array}$ & $27.21(25.03-28.29)$ & $-0.67(-0.71--0.63)$ \\
\hline \multicolumn{6}{|l|}{ Socio-demographic factor } \\
\hline High SDI & $828.98(750.18-851.84)$ & $68.29(61.81-70.16)$ & $\begin{array}{l}1289.66(1214.29- \\
1335.62)\end{array}$ & $66.08(62.70-68.45)$ & $-0.23(-0.32--0.15)$ \\
\hline High-middle SDI & $529(469.86-569.13)$ & $52.00(46.34-55.91)$ & $843.42(798.96-879.28)$ & $48.22(45.83-50.23)$ & $-0.34(-0.47--0.22)$ \\
\hline Middle SDI & $293.74(274.47-319.99)$ & 23.55 (22.19-25.50) & $620.20(575.96-660.73)$ & $27.83(26.06-29.59)$ & $0.66(0.62-0.71)$ \\
\hline Low-middle SDI & $154.97(127.78-187.76)$ & 18.40 (15.93-21.49) & $332.52(305.98-357.67)$ & $23.73(21.89-25.43)$ & $0.93(0.89-0.96)$ \\
\hline Low SDI & $103.7(66.24-154.98)$ & $17.59(13.07-24.26)$ & $189.05(160.88-214.37)$ & $19.20(16.35-21.54)$ & $0.30(0.18-0.43)$ \\
\hline \multicolumn{6}{|l|}{ Region } \\
\hline Andean Latin America & $14.16(12.44-15.65)$ & $47.50(41.17-51.57)$ & 25.82 (22.59-28.92) & $46.02(40.19-51.29)$ & $-0.27(-0.47--0.06)$ \\
\hline Australasia & 17.7 (15.63-18.46) & $75.79(67.21-79.05)$ & $31.61(28.62-34.96)$ & $73.12(66.28-80.9)$ & $-0.29(-0.34--0.24)$ \\
\hline Caribbean & $18.48(13.95-22.23)$ & $59.99(45.5-70.56)$ & $20.95(18.80-25.11)$ & $42.6(38.09-51.12)$ & $-1.22(-1.64--0.79)$ \\
\hline Central Asia & $30.12(25.58-34.93)$ & $53.43(44.63-63.17)$ & $52.34(49.29-55.11)$ & $62.42(58.91-65.65)$ & $0.38(0.24-0.51)$ \\
\hline Central Europe & $110.83(103.52-114.07)$ & 74.80 (69.81-76.99) & $175.47(155.5-184.35)$ & $90.34(80.08-94.73)$ & $0.88(0.68-1.09)$ \\
\hline Central Latin America & $53.16(47.16-54.97)$ & $45.23(40.77-46.72)$ & $126.95(120.72-133.94)$ & $52.44(49.88-55.37)$ & $0.6(0.52-0.69)$ \\
\hline $\begin{array}{l}\text { Central Sub-Saharan } \\
\text { Africa }\end{array}$ & $11.10(6.42-17.06)$ & $24.08(18.64-31.37)$ & $20.76(16.72-25.24)$ & $24.47(20.51-29.51)$ & $-0.05(-0.18-0.09)$ \\
\hline East Asia & $229.95(207.43-275.71)$ & $20.84(18.82-25.49)$ & $472.46(417.97-507.41)$ & 25.15 (22.46-26.95) & $1.13(0.92-1.33)$ \\
\hline Eastern Europe & $244.68(212.02-274.15)$ & 87.5 (75.87-97.79) & $318.58(304.82-330.17)$ & $98.87(94.69-102.7)$ & $0.18(-0.12-0.47)$ \\
\hline $\begin{array}{l}\text { Eastern Sub-Saharan } \\
\text { Africa }\end{array}$ & $40.17(23.58-65.07)$ & $23.34(16.67-34.25)$ & $66.59(54.91-79.91)$ & $22.79(19.51-26.36)$ & $-0.23(-0.34--0.12)$ \\
\hline $\begin{array}{l}\text { High-income Asia } \\
\text { Pacific }\end{array}$ & $72.28(70.38-76.52)$ & $35.45(34.47-37.66)$ & $149.03(134.76-159.4)$ & $39.63(35.93-42.70)$ & $0.38(0.18-0.59)$ \\
\hline $\begin{array}{l}\text { High-income North } \\
\text { America }\end{array}$ & $263.79(238.77-272.98)$ & 79.85 (72.31-82.71) & $407.78(387.52-435.78)$ & $72.6(68.88-77.99)$ & $-0.62(-0.72--0.52)$ \\
\hline $\begin{array}{l}\text { North Africa and Mid- } \\
\text { dle East }\end{array}$ & $67.12(50.45-86.17)$ & $25.30(20.27-31.00)$ & $140.56(120.36-150.18)$ & $28.67(24.82-30.66)$ & $0.65(0.53-0.77)$ \\
\hline Oceania & $0.96(0.74-1.22)$ & $21.72(17.04-27.9)$ & $2.28(1.78-2.92)$ & $24.44(19.16-30.90)$ & $0.50(0.44-0.56)$ \\
\hline South Asia & 104.55 (82.2-134.68) & $12.59(10.39-15.56)$ & $251.84(225.69-265.85)$ & $16.76(15.01-17.69)$ & $0.98(0.88-1.09)$ \\
\hline Southeast Asia & 76.04 (62.63-88.55) & $21.92(19.02-24.93)$ & $176.89(149.46-192.46)$ & $28.11(23.79-30.55)$ & $0.72(0.49-0.95)$ \\
\hline $\begin{array}{l}\text { Southern Latin } \\
\text { America }\end{array}$ & $60.96(44.73-64.64)$ & $126.5(92.75-134.2)$ & $80.86(73.15-90.63)$ & 103.09 (93.24-115.75) & $-0.76(-1.07--0.45)$ \\
\hline $\begin{array}{l}\text { Southern Sub-Saharan } \\
\text { Africa }\end{array}$ & $10.16(9.12-11.31)$ & 26.39 (23.39-29.43) & $19.10(16.97-21.29)$ & $30.27(26.95-33.54)$ & $0.47(0.02-0.91)$ \\
\hline Tropical Latin America & $47.28(43.26-49.74)$ & $38.56(35.48-40.15)$ & $107.71(102.44-112.13)$ & $46.71(44.32-48.56)$ & $0.73(0.69-0.78)$ \\
\hline Western Europe & 405.97 (359.81-418.97) & 75.35 (67.02-77.76) & $553.19(510.18-582.26)$ & 70.68 (65.64-74.49) & $-0.34(-0.39--0.29)$ \\
\hline $\begin{array}{l}\text { Western Sub-Saharan } \\
\text { Africa }\end{array}$ & $36.02(27.06-47.51)$ & $22.05(17.85-27.27)$ & 83.55 (70.63-98.56) & $26.42(22.8-30.72)$ & $0.50(0.37-0.63)$ \\
\hline
\end{tabular}

the necessity of smoking cessation to the public to minimize kidney cancer's burden.

In the GBD database, we observed that occupational exposure to trichloroethylene was also a contributor to kidney cancer-related mortality. It has been reported that the relationship between trichloroethylene and kidney cancer risk is dose-response with trichloroethylene exposure level [4]. Kidney is the main target of 

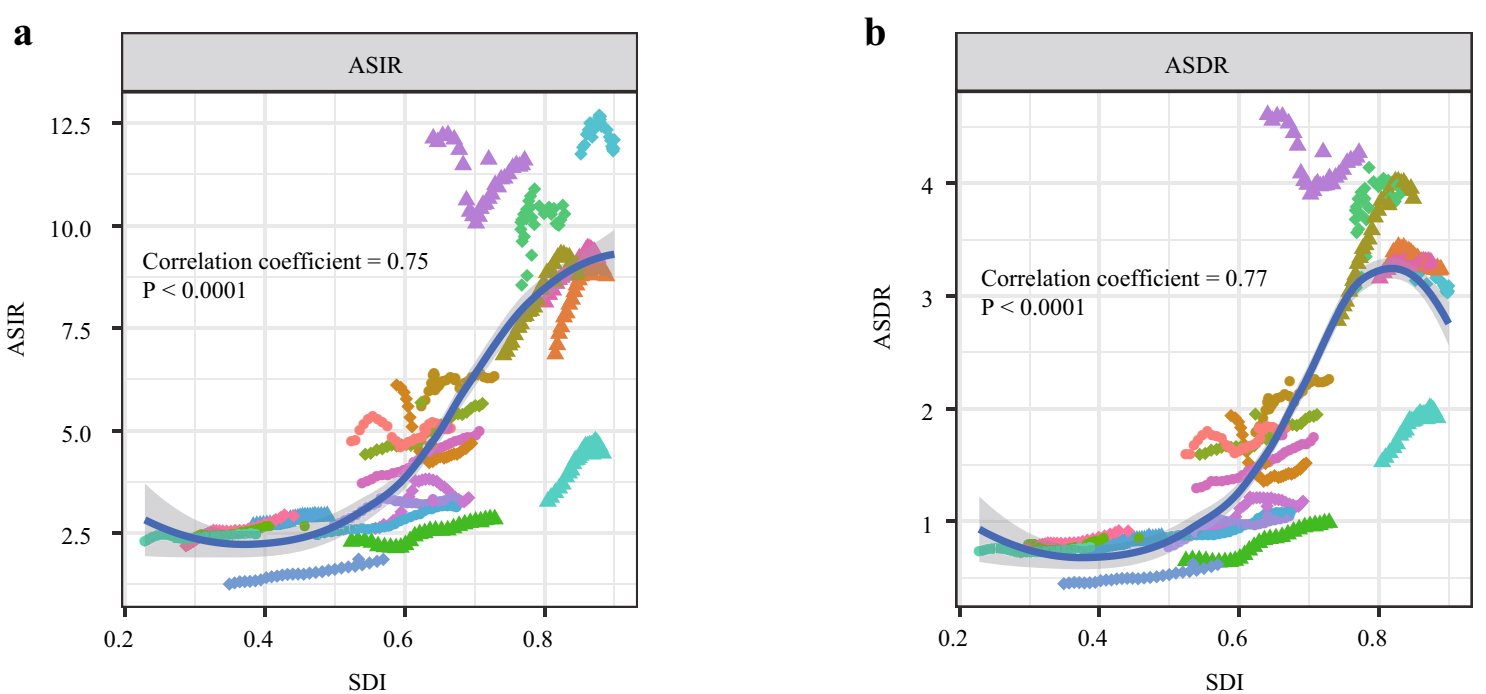

Location
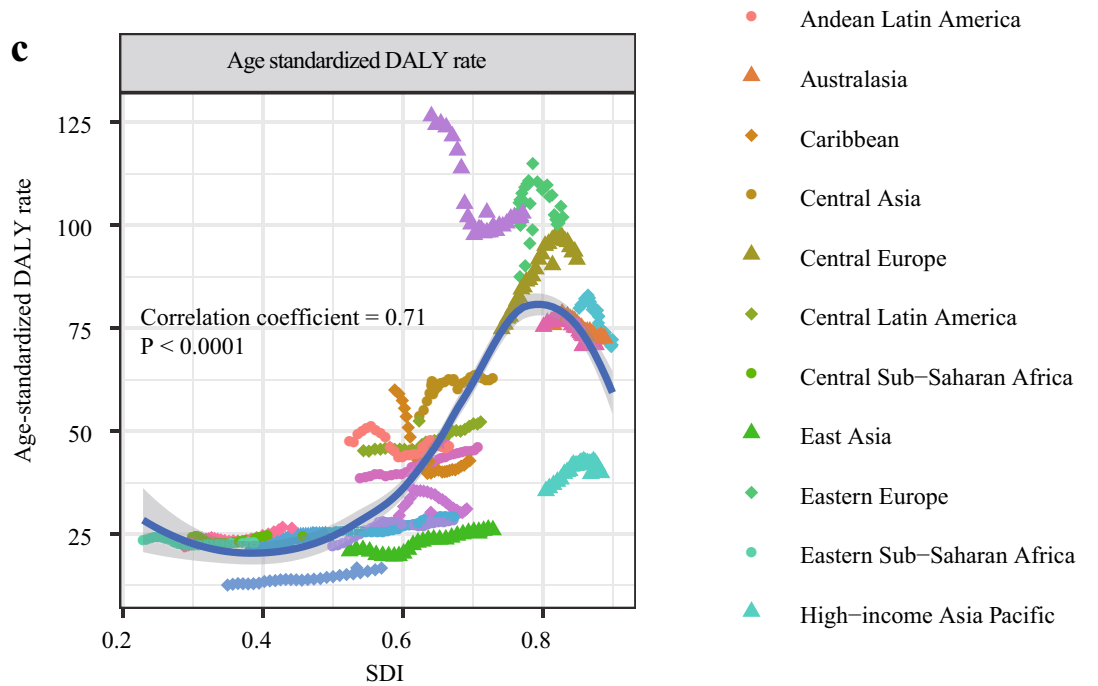

High-income North America

- North Africa and Middle East

$\Delta \quad$ Oceania

- South Asia

- Southeast Asia

$\Delta \quad$ Southern Latin America

Southern Sub-Saharan Africa

- Tropical Latin America

- Western Europe

Western Sub-Saharan Africa

Fig. 5 The correlation analyses of ASRs and SDI values from 1990 to 2017. a The correlation of ASIR and SDI from 1990 to 2017. b The correlation of ASDR and SDI from 1990 to 2017. c The correlation of age-standardized DALY rate and SDI from 1990 to 2017. Note: ASIR, Age-standardized incidence rate; ASDR, Age-standardized death rate; DALY, disability-adjusted life year; SDI, Socio-demographic Index

trichloroethylene [43]. The nephrotoxic and potential nephrocarcinogenic effects of trichloroethylene occur predominantly by GST conjugation and bio-activation by renal CCLB1 [44]. Protection against occupational exposure is necessary, especially for individuals in the organic/ chlorinated solvent industry.

Generally, developed countries with high SDI had the highest kidney cancer's burden but had a slight decrease in incidence rate. On the contrary, the incidence rate was rapidly increased in developing countries with low-middle SDI countries, although the burden of kidney cancer kept relatively low until 2017. The elderly population was the group with the highest risk of developing kidney cancer. With more countries facing an aging population, it is important to be aware of the potentially increased burden of kidney cancer. Lastly, attributable risk factor analysis showed that the high body-mass index and smoking were the main factors contributing to kidney cancer-related mortality. Reinforcing a healthy lifestyle to the public would be helpful to minimize kidney cancer's burden in the future. 

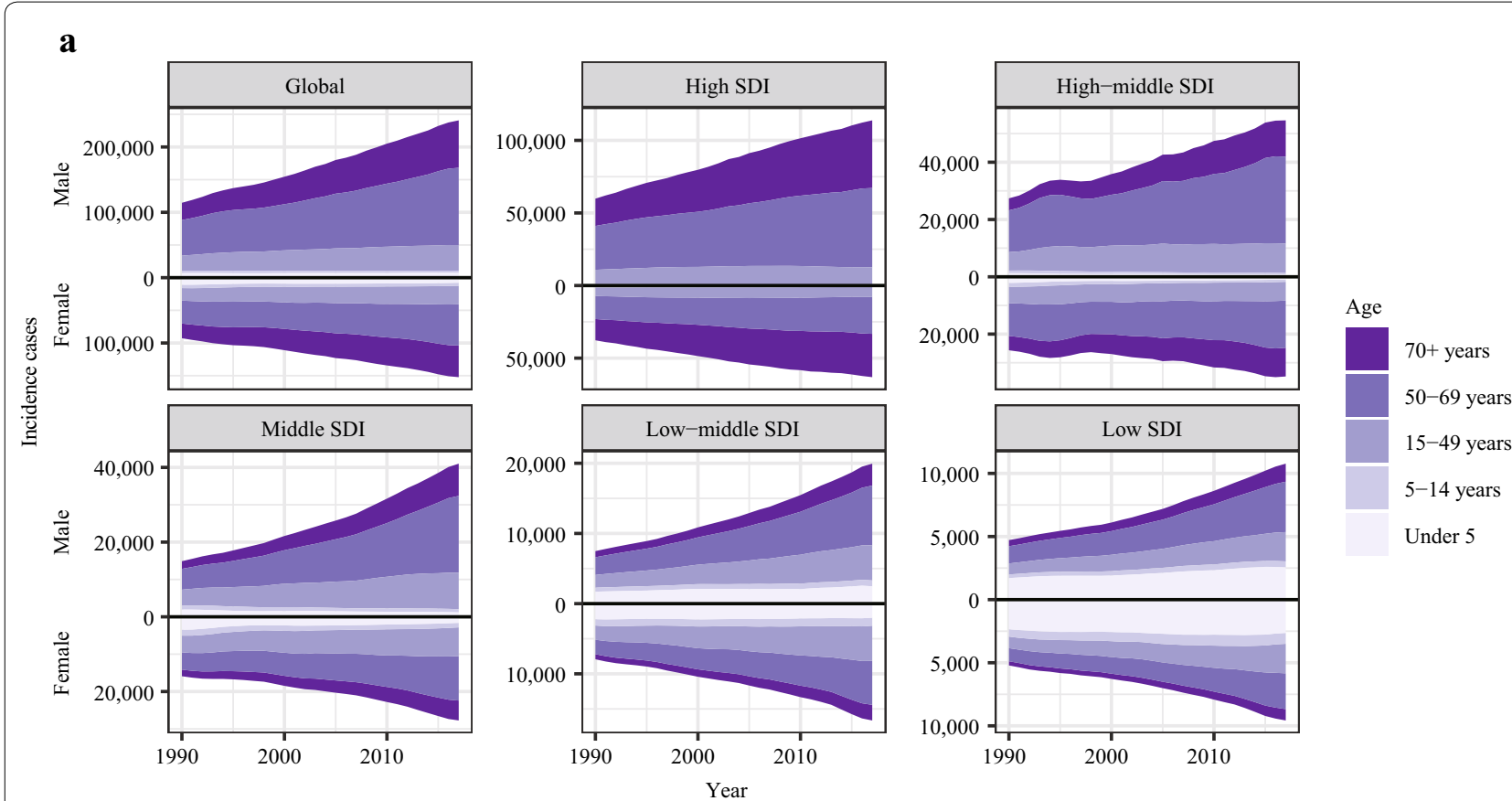

\section{b}
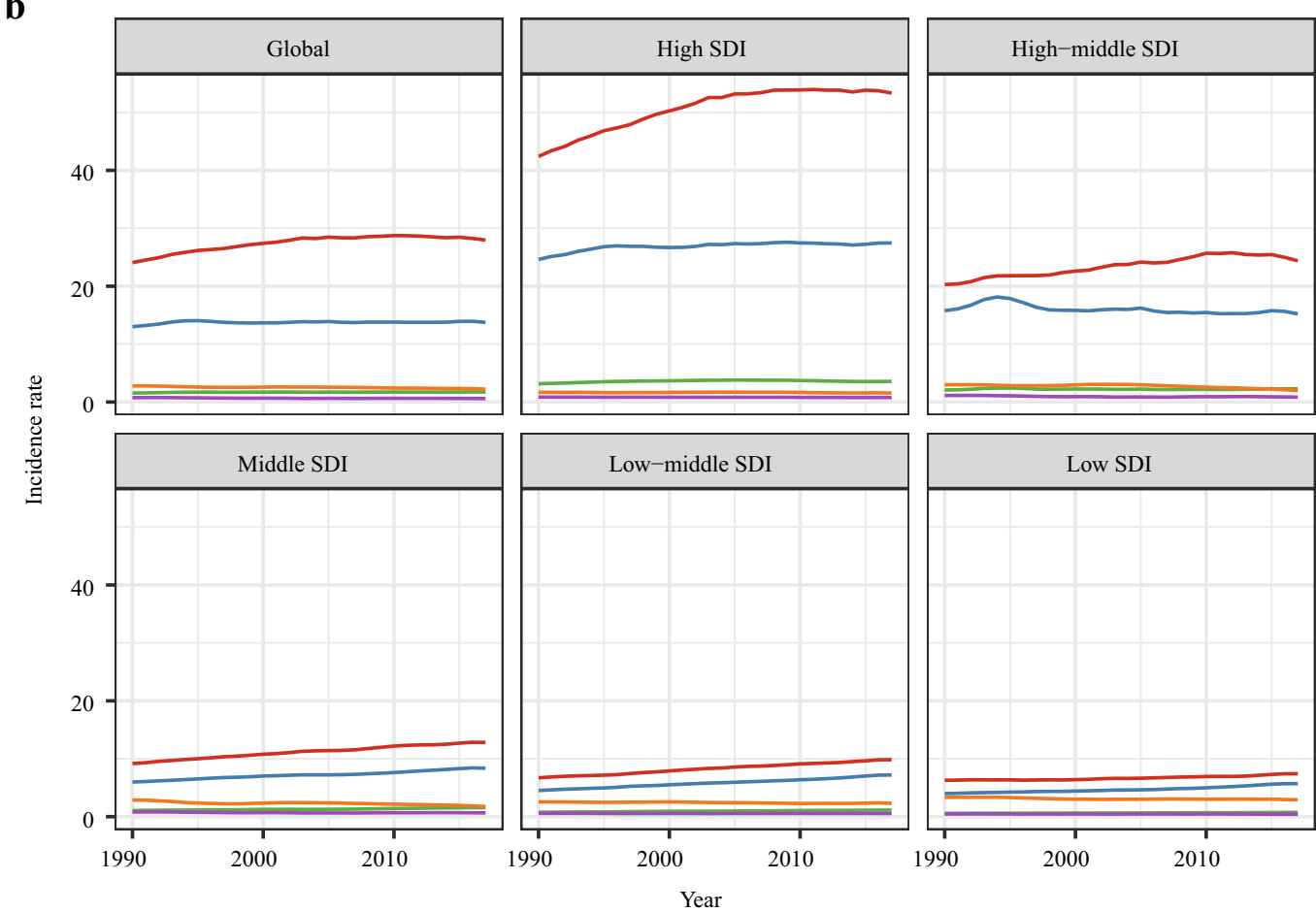

Age

- $70+$ years

— 50-69 years

— 15-49 years

— 5-14 years

— Under 5

Fig. 6 The change trends of incidence and ASIR of kidney cancer in different age groups. a The incidence cases of kidney cancer in five different age groups in the globe and in various regions. The ASIR of kidney cancer in five different age groups in the world and in various regions. Note: ASIR, Age-standardized incidence rate; SDI, Socio-demographic Index

\section{Conclusion}

In the present study, we performed a comprehensive analysis to assess the burden of kidney cancer in the globe, different areas, and 195 countries from 1990 to 2017. The incidence of kidney cancer kept growing in the past 28 years. Generally, developed countries with 

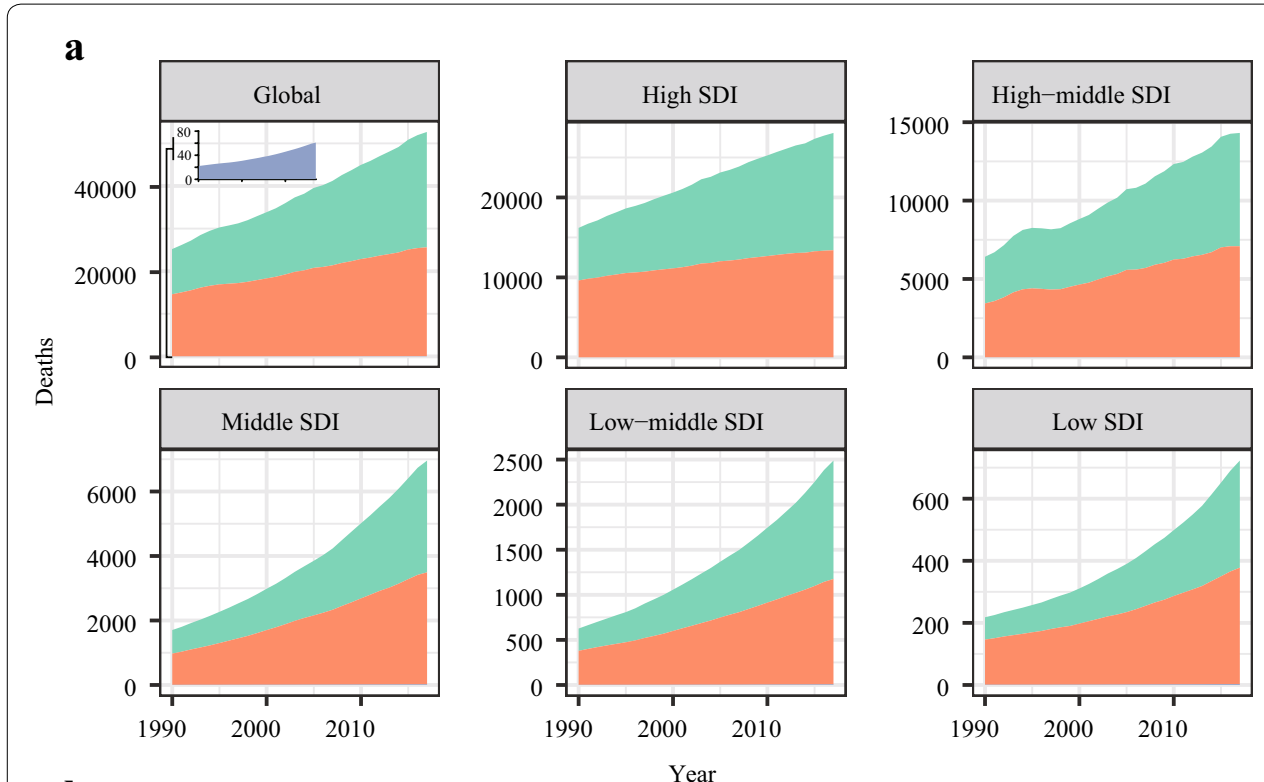

Risk factors
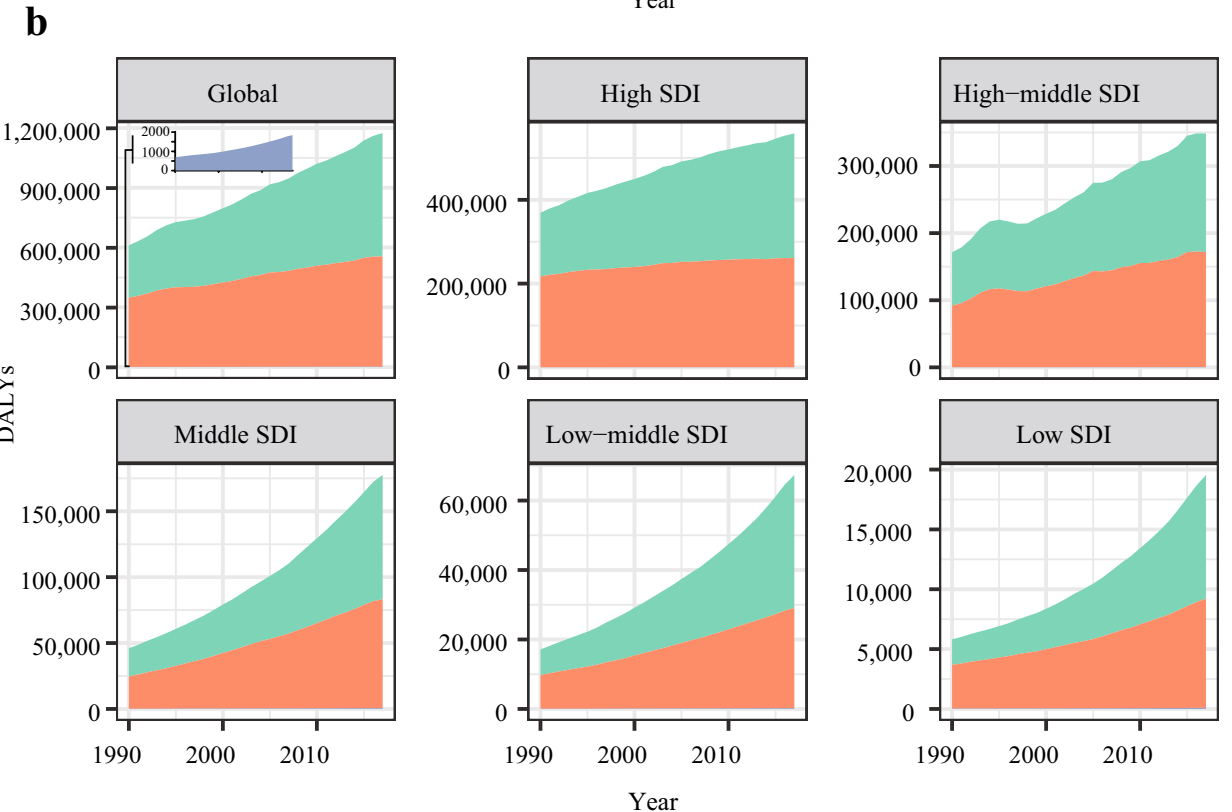

Risk factors

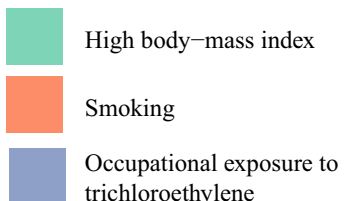

Fig. 7 Risk factors contributing to kidney cancer-related death and DALY. a Three risk factors contributing to kidney cancer-related death from 1990 to 2017 in the globe and different regions; b three risk factors contributing to AML-related DALY from 1990 to 2017 in the world and different regions; Note: DALY, disability-adjusted life year; SDI, Socio-demographic Index

high SDI had the highest kidney cancer's burden but had a slight decrease in incidence rate. On the contrary, the incidence rate was rapidly increased in developing countries with low-middle SDI countries, although the burden of kidney cancer kept relatively low until 2017. The elderly population was the group with the highest risk of developing kidney cancer. With more countries facing an aging population, it is important to be aware of the potentially increased burden of kidney cancer. Lastly, attributable risk factor analysis showed that the high body-mass index and smoking were the main factors contributing to kidney cancer-related mortality. Reinforcing a healthy lifestyle to the public would be helpful to minimize kidney cancer's burden in the future.

\section{Abbreviations}

GBD: Global burden disease; DALY: Disability-adjusted life year; SDI:

Socio-demographic Index; ASIR: Age-standardized incidence rate; ASDR: 
Age-standardized death rate; EAPC: Estimated annual percentage change; ASR: Age-standardized rate.

\section{Acknowledgements}

Not applicable.

\section{Authors' contributions}

All authors contributed to research performing, drafting and revising the article, gave final approval of the version to be published, and agree to be accountable for all aspects of the work. All authors read and approved the final manuscript.

\section{Funding}

This work was supported by the National Natural Science Foundation of China (No. 81874120), Wuhan Science and Technology Bureau (No. 2017060201010170), and National Cancer Center Climbing Foundation Key Project (NCC201816B046). This work was also supported by Henan Provincial Key Science and Technology Research Projects (No.182102310181 and No.192102310087).

\section{Availability of data and materials}

The datasets generated during and/or analyzed during the current study are available from the Global Health Data Exchange query tool (http://ghdx.healt hdata.org/gbd-results-tool).

\section{Ethics approval and consent to participate}

Not applicable.

\section{Consent for publication}

Not applicable.

\section{Competing interests}

The authors declare that they have no competing interests.

\section{Author details}

${ }^{1}$ Medical School of Pingdingshan University, Pingdingshan, Henan, China.

${ }^{2}$ Department of Oncology, Tongji Hospital of Tongji Medical College, Huazhong University of Science and Technology, Wuhan, Hubei, China

${ }^{3}$ Department of Molecular Pathology, The Affiliated Cancer Hospital of Zhengzhou University and Henan Cancer Hospital, Zhengzhou, Henan, China.

Received: 22 Auqust 2020 Accepted: 15 September 2020

Published online: 29 September 2020

\section{References}

1. Siegel RL, Miller KD, Jemal A. Cancer statistics, 2019. CA Cancer J Clin. 2019;69:7-34

2. Levi F, Ferlay J, Galeone C, Lucchini F, Negri E, Boyle P, et al. The changing pattern of kidney cancer incidence and mortality in Europe. BJU Int. 2008;101:949-58.

3. Capitanio U, Montorsi F. Renal cancer. Lancet. 2016;387:894-906.

4. Chow WH, Dong LM, Devesa SS. Epidemiology and risk factors for kidney cancer. Nat Rev Urol. 2010;7:245-57.

5. Siegel R, Ma J, Zou Z, Jemal A. Cancer statistics, 2014. CA Cancer J Clin. 2014;64:9-29

6. Qin S, Li A, Yi M, Yu S, Zhang M, Wu K. Recent advances on anti-angiogenesis receptor tyrosine kinase inhibitors in cancer therapy. J Hematol Oncol. 2019;12:27.

7. Sanchez-Gastaldo A, Kempf E, Gonzalez Del Alba A, Duran I. Systemic treatment of renal cell cancer: a comprehensive review. Cancer Treat Rev. 2017;60:77-89.

8. Kajiwara M, Masuda S. Role of mTOR inhibitors in kidney disease. Int J Mol Sci. 2016;17:975.

9. Yi M, Qin S, Zhao W, Yu S, Chu Q, Wu K. The role of neoantigen in immune checkpoint blockade therapy. Exp Hematol Oncol. 2018;7:28.

10. Li X, Shao C, Shi Y, Han W. Lessons learned from the blockade of immune checkpoints in cancer immunotherapy. J Hematol Oncol. 2018;11:31.

11. Yi M, Jiao D, Xu H, Liu Q, Zhao W, Han X, et al. Biomarkers for predicting efficacy of PD-1/PD-L1 inhibitors. Mol Cancer. 2018;17:129.
12. Choueiri TK, Larkin J, Oya M, Thistlethwaite F, Martignoni M, Nathan P, et al. Preliminary results for avelumab plus axitinib as first-line therapy in patients with advanced clear-cell renal-cell carcinoma (JAVELIN Renal 100): an open-label, dose-finding and dose-expansion, phase $1 \mathrm{~b}$ trial. Lancet Oncol. 2018;19:451-60.

13. Yi M, Jiao D, Qin S, Chu Q, Wu K, Li A. Synergistic effect of immune checkpoint blockade and anti-angiogenesis in cancer treatment. Mol Cancer. 2019;18:60

14. Shuch B, Amin A, Armstrong AJ, Eble JN, Ficarra V, Lopez-Beltran A, et al. Understanding pathologic variants of renal cell carcinoma: distilling therapeutic opportunities from biologic complexity. Eur Urol. 2015;67:85-97.

15. Chu Q, Han N, Yuan X, Nie X, Wu H, Chen Y, et al. DACH1 inhibits cyclin D1 expression, cellular proliferation and tumor growth of renal cancer cells. J Hematol Oncol. 2014;7:73.

16. Srinivasan R, Ricketts CJ, Sourbier C, Linehan WM. New strategies in renal cell carcinoma: targeting the genetic and metabolic basis of disease. Clin Cancer Res. 2015;21:10-7.

17. Moore LE, Nickerson ML, Brennan P, Toro JR, Jaeger E, Rinsky J, et al. Von Hippel-Lindau (VHL) inactivation in sporadic clear cell renal cancer: associations with germline VHL polymorphisms and etiologic risk factors. PLoS Genet. 2011;7:e1002312

18. Sidaway P. Kidney cancer: Bap1 and Pbrm1 determine tumour grade. Nat Rev Urol. 2017;14:391

19. Gerlinger M, Rowan AJ, Horswell S, Math M, Larkin J, Endesfelder D, et al. Intratumor heterogeneity and branched evolution revealed by multiregion sequencing. N Engl J Med. 2012;366:883-92.

20. Morris MR, Latif F. The epigenetic landscape of renal cancer. Nat Rev Nephrol. 2017;13:47-60

21. Hakimi AA, Tickoo SK, Jacobsen A, Sarungbam J, Sfakianos JP, Sato Y, et al. TCEB1-mutated renal cell carcinoma: a distinct genomic and morphological subtype. Mod Pathol. 2015:28:845-53.

22. Gati A, Kouidhi S, Marrakchi R, El Gaaied A, Kourda N, Derouiche A, et al. Obesity and renal cancer: role of adipokines in the tumor-immune system conflict. Oncoimmunology. 2014;3:e27810.

23. Theis RP, Dolwick Grieb SM, Burr D, Siddiqui T, Asal NR. Smoking, environmental tobacco smoke, and risk of renal cell cancer: a population-based case-control study. BMC Cancer. 2008:8:387.

24. Hunt JD, van der Hel OL, McMillan GP, Boffetta P, Brennan P. Renal cell carcinoma in relation to cigarette smoking: meta-analysis of 24 studies. Int J Cancer. 2005:114:101-8.

25. Renehan AG, Tyson M, Egger M, Heller RF, Zwahlen M. Body-mass index and incidence of cancer: a systematic review and meta-analysis of prospective observational studies. Lancet. 2008;371:569-78.

26. Weikert S, Boeing H, Pischon T, Weikert C, Olsen A, Tjonneland A, et al. Blood pressure and risk of renal cell carcinoma in the European prospective investigation into cancer and nutrition. Am J Epidemiol. 2008;167:438-46.

27. Lee JE, Männistö S, Spiegelman D, Hunter DJ, Bernstein L, van den Brandt PA, et al. Intakes of fruit, vegetables, and carotenoids and renal cell cancer risk: a pooled analysis of 13 prospective studies. Cancer Epidemio Biomarkers Prev. 2009;18:1730-9.

28. Yi M, Li A, Zhou L, Chu Q, Song Y, Wu K. The global burden and attributable risk factor analysis of acute myeloid leukemia in 195 countries and territories from 1990 to 2017: estimates based on the global burden of disease study 2017. J Hematol Oncol. 2020;13:72.

29. Zhou L, Deng Y, Li N, Zheng Y, Tian T, Zhai Z, et al. Global, regional, and national burden of Hodgkin lymphoma from 1990 to 2017: estimates from the 2017 Global Burden of Disease study. J Hematol Oncol. 2019;12:107.

30. Feigin VL, Forouzanfar MH, Krishnamurthi R, Mensah GA, Connor M, Bennett DA, et al. Global and regional burden of stroke during 1990-2010: findings from the Global Burden of Disease Study 2010. Lancet. 2014;383:245-54

31. Li N, Deng Y, Zhou L, Tian T, Yang S, Wu Y, et al. Global burden of breast cancer and attributable risk factors in 195 countries and territories, from 1990 to 2017: results from the Global Burden of Disease Study 2017. J Hematol Oncol. 2019;12:140.

32. Yi M, Zhou L, Li A, Luo S, Wu K. Global burden and trend of acute lymphoblastic leukemia from 1990 to 2017. In: Aging, vol. 12. Albany NY: Advance; 2020 
33. Znaor A, Lortet-Tieulent J, Laversanne M, Jemal A, Bray F. International variations and trends in renal cell carcinoma incidence and mortality. Eur Urol. 2015;67:519-30.

34. Arabsalmani M, Mohammadian-Hafshejani A, Ghoncheh M, Hadadian F, Towhidi F, Vafaee K, et al. Incidence and mortality of kidney cancers, and human development index in Asia; a matter of concern. J Nephropathol. 2017;6:30-42.

35. Patel AR, Prasad SM, Shih YC, Eggener SE. The association of the human development index with global kidney cancer incidence and mortality. J Urol. 2012;187:1978-83.

36. Nam GE, Cho KH, Han K, Kim CM, Han B, Cho SJ, et al. Obesity, abdominal obesity and subsequent risk of kidney cancer: a cohort study of 23.3 million East Asians. Br J Cancer. 2019;121:271-7.

37. Bergström A, Hsieh CC, Lindblad P, Lu CM, Cook NR, Wolk A. Obesity and renal cell cancer-a quantitative review. Br J Cancer. 2001;85:984-90.

38. Macleod LC, Hotaling JM, Wright JL, Davenport MT, Gore JL, Harper J, et al. Risk factors for renal cell carcinoma in the VITAL study. J Urol. 2013;190:1657-61.

39. Gild $P$, Ehdaie $B$, Kluth LA. Effect of obesity on bladder cancer and renal cell carcinoma incidence and survival. Curr Opin Urol. 2017;27:409-14.

40. Cumberbatch MG, Rota M, Catto JW, La Vecchia C. The role of tobacco smoke in bladder and kidney carcinogenesis: a comparison of exposures and meta-analysis of incidence and mortality risks. Eur Urol. 2016;70:458-66.

41. Ehdaie B, Furberg H, Zabor EC, Hakimi AA, Russo P. Comprehensive assessment of the impact of cigarette smoking on survival of clear cell kidney cancer. J Urol. 2014;191:597-602.

42. Tsivian M, Moreira DM, Caso JR, Mouraviev V, Polascik TJ. Cigarette smoking is associated with advanced renal cell carcinoma. J Clin Oncol. 2011;29:2027-31.

43. Scott CS, Chiu WA. Trichloroethylene cancer epidemiology: a consideration of select issues. Environ Health Perspect. 2006;114:1471-8.

44. Moore LE, Boffetta P, Karami S, Brennan P, Stewart PS, Hung R, et al. Occupational trichloroethylene exposure and renal carcinoma risk: evidence of genetic susceptibility by reductive metabolism gene variants. Cancer Res. 2010;70:6527-36.

\section{Publisher's Note}

Springer Nature remains neutral with regard to jurisdictional claims in published maps and institutional affiliations.
Ready to submit your research? Choose BMC and benefit from:

- fast, convenient online submission

- thorough peer review by experienced researchers in your field

- rapid publication on acceptance

- support for research data, including large and complex data types

- gold Open Access which fosters wider collaboration and increased citations

- maximum visibility for your research: over $100 \mathrm{M}$ website views per year

At BMC, research is always in progress.

Learn more biomedcentral.com/submissions 